\title{
Jarosław Michalski, Rzecz o takcie pedagogicznym nauczyciela, Warszawa: Wydawnictwo Akademii Pedagogiki Specjalnej, 2013, ss. 198.
}

DOI: http://dx.doi.org/10.12775/PCh.2015.02।

Słowo „takt” używane jest w różnych sytuacjach życia codziennego, ponieważ związane jest z refleksją o człowieku, z doświadczaniem przez niego obecności drugiej osoby oraz podmiotowego współistnienia, współtworzenia rzeczywistości. Dlatego ma ogromne znaczenie w wielu obszarach ludzkiego funkcjonowania, między innymi w kulturze, w polityce, w gospodarce, w edukacji. Uczy w tych sferach nie tylko zasad dobrego wychowania, ale także uwzględniania uczuć drugiego człowieka oraz zachowania adekwatnego do zaistniałych okoliczności. Znaczenie tego terminu wciąż odkrywane jest w różnorodnych dyskursach, w tym również w dyskursach naukowych. Takt bywa różnie interpretowany przez przedstawicieli nauk humanistycznych, między innymi pedagogiki, filozofii, literatury, psychologii czy socjologii. Trzeba podkreślić, że synkretyczne ujęcie przyczynia się do wzbogacenia znaczeniowego tego pojęcia.

Zastanówmy się, jak takt jest rozumiany na gruncie pedagogiki, w szczególności w zakresie pedeutologii? Należy zaznaczyć, że badacze nadal poszukują czynników, które decydują o wartości nauczyciela oraz wpływają na efektywność jego działalności. Zastanawiają się: kim jest?; kim powinien być?; kim chce być nauczyciel? Z analizy myśli pedeutologicznej wynika, że właściwości osobowościowe warunkują powodzenie w zawodzie pedagogicznym. Dlatego poznanie i ustalenie najbardziej wartościowych cech nauczyciela ma ogromne znaczenie zarówno w zakresie jego pragmatycznych zobowiązań, jak i w percepcji własnej osoby. Moga one przyczynić się do większej samoświadomości, oceny własnej postawy oraz stosunku do wykonywanej profesji, jak i tworzenia planów dalszego rozwoju zawodowego. Wśród tych właściwości osobowych niezwykle ważne miejsce zajmuje takt pedagogiczny. O jego znaczeniu w pracy pedagogicznej przekonywali między innymi: Johann Friedrich Herbart ${ }^{1}$, Stefan

nała Stefana Wyszyńskiego w Warszawie. Adres: Wydział Nauk Pedagogicznych UKSW, ul. Wóycickiego 1/3, budynek nr 15, 01-938 Warszawa; e-mail: d.stepkowski@uksw.edu.pl.

1 Johann Friedrich Herbart, Pedagogika ogólna wywiedziona z celu wychowania (Warszawa: Gebethner i Wolff, 1912). 
Baley $^{2}$, Zygmunt Mysłakowski ${ }^{3}$, Henryk Rowid ${ }^{4}$, Grzegorz Burzyński ${ }^{5}$, Julian Radziewicz ${ }^{6}$, Wincenty Choma ${ }^{7}$. Do grona autorów, którzy docenili tę tematykę na gruncie pedagogiki dołączył Jarosław Michalski ${ }^{8}$, autor prac poświęconych problematyce pedeutologicznej oraz metodyce nauczania. Recenzowana publikacja: Rzecz o takcie pedagogicznym nauczyciela, jest kontynuacją myśli nad taktem pedagogicznym, jaką J. Michalski zapoczątkował w wydanej w 2010 roku książce: Takt pedagogiczny w sztuce nauczycielskiego działania. Podkreślił on, że ,pedagogiczny takt to dawny i ciagle zarazem nowy temat, jak i samo wychowanie, jak sama pedagogika, bo jak wiadomo, w każdym zawodzie jest coś specyficznego. Co odróżnia zawód nauczyciela od innych? Dla nauczyciela ta specyfika najbardziej przejawia się w pedagogicznym takcie. Pedagogiczny takt dla nauczyciela jest tym, czym dla śpiewaka głos albo słuch dla muzyka" (s. 65).

Recenzowana książka zawiera teoretyczne rozważania na temat taktu pedagogicznego. Należy zaznaczyć, że współcześnie ta problematyka jest pomijana i niedoceniana $\mathrm{w}$ środowisku naukowym, jak i w rzeczywistości szkolnej. Niewielu badaczy podejmuje się analizy tej tematyki oraz w niewielkim zakresie pojawia się ona w programach kształcenia i doskonalenia zawodowego nauczycieli. Tym bardziej należy docenić obszar badawczy wybrany przez J. Michalskiego. Zdecydował się na analizę zagadnienia z zakresu pedeutologii, gdyż - jak podkreślił - współcześnie z jednej strony pojawia się tendencja do eliminowania trudnych kategorii edukacyjnych, tym samym pomijane są nowe problemy pedagogiczne, a z drugiej strony występuje potrzeba myślenia humanistycznego, z uwagi na skomplikowany

2 Stefan Baley, Psychologia wychowawcza w zarysie (Warszawa: Państwowe Wydawnictwo Naukowe, 1958).

3 Zygmunt Mysłakowski, „Tresura czy wychowanie”, Nowa Szkoła 11 (1969); Zygmunt Mysłakowski, Pisma wybrane (Warszawa: Państwowe Zakłady Wydawnictw Szkolnych, 1971).

${ }^{4}$ Henryk Rowid, Podstawy i zasady wychowania (Warszawa: Wspólna Sprawa, 1957).

${ }^{5}$ Grzegorz Burzyński, Takt pedagogiczny $w$ wychowaniu współczesnego człowieka (Lublin, 1937).

6 Julian Radziewicz, ,Takt i nietakt w wychowaniu”, Nowa Szkoła 5 (1996).

7 Wincenty Choma, „Takt pedagogiczny”, Ruch Pedagogiczny 3 (1961).

8 Jarosław Michalski - wykładowca w Akademii Pedagogiki Specjalnej im. Marii Grzegorzewskiej w Warszawie. Autor prac: Z notatnika metodyka (Warszawa: Centralny Ośrodek Doskonalenia, 2000); Nauczyciel szkoły specjalnej: szanse $i$ bariery działalności zawodowej (Warszawa: Wydawnictwo Akademii Pedagogiki Specjalnej, 2002); Takt pedagogiczny w sztuce nauczycielskiego działania (Warszawa: Wydawnictwo Akademii Pedagogiki Spe- 
charakter pracy nauczyciela. Autor zwrócił uwagę, iż ,pedagogika bez taktu zaznacza jedynie niewyraźne schematy odniesień, a uczniom potrzebne są ich bardzo wyraźne kontury, które wskażą nie tylko ich miejsce, lecz także możliwości przejścia do innych sfer, które przez okazywany im szacunek, akceptację i umożliwianie samodzielnych decyzji doprowadzą do sukcesu osobistego i społecznego" (s. 51-52). Tym samym nie można podważać znaczenia taktu pedagogicznego w zakresie teorii i praktyki edukacyjnej, gdyż stanowi on łącznik pomiędzy tymi dwoma obszarami, niezbędnymi w procesie rozwoju zawodowego pedagogów.

Podejmowana w pracy pt. Rzecz o takcie pedagogicznym nauczyciela problematyka została zaprezentowana $\mathrm{w}$ pięciu rozdziałach. Pierwszy rozdział (Wprowadzenie do problematyki taktu) J. Michalski poświęcił ogólnym rozważaniom dotyczącym tworzenia pojęć humanistycznych, ze szczególnym zwróceniem uwagi na słowo takt. Poza tym uwzględnił aspekt synonimiczny oraz różne podejścia do rozumienia znaczenia tego terminu. Podkreślił, że takt jest kategorią abstrakcyjną, a zarazem skomplikowaną badawczo ze względu na trudność odpowiedniego uzasadnienia naukowego, wynikającą ze złożoności paradygmatów i teorii pedagogicznych. W drugim rozdziale (Geneza taktu pedagogicznego i ujęcie interpretacyjne) autor nawiązał do poglądów między innymi: Johana Friedricha Herbarta, Janusza Korczaka, Zygmunta Mysłakowskiego, Stefana Baleya czy Wincentego Okonia, a także odniósł się do współczesnych twórców (Bogusława Śliwerskiego, Czesława Kupisiewicza, Małgorzaty Kupisiewicz), którzy w swoich badaniach podejmuja problematykę taktu pedagogicznego. W trzecim rozdziale (Charakterystyka wybranych nurtów teoretycznych z odniesieniem do taktu pedagogicznego) J. Michalski dokonał analizy taktu pedagogicznego z perspektywy różnorodnych koncepcji wychowania, sytuując go w zakresie pedagogiki filozoficznej, pedagogiki serca, pedagogiki międzykulturowej, pedagogiki humanistycznej oraz nurtu Nowego Wychowania. Czwarty rozdział (Pedeutologiczny obszar rozważań nad taktem pedagogicznym) zawiera różne koncepcje, perspektywy oraz kierunki rozwoju pedeutologii. Celem zobrazowania tej problematyki autor odwołał się do twórczości tych, którzy tworzyli polską myśl pedeutologiczną, między innymi Józefa Mirskiego, Marii Grzegorzewskiej czy Stanisława Dobrowolskiego, a także wskazał nowe perspektywy analizy działalności nauczyciela z wykorzystaniem

cjalnej, 2010); Rzecz o takcie pedagogicznym nauczyciela (Warszawa: Wydawnictwo Akademii Pedagogiki Specjalnej, 2013). 
bieżących osiągnięć badaczy. W ostatnim rozdziale (Dyskurs pedagogiczny na temat taktu pedagogicznego) J. Michalski dokonał przeglądu dyskursu dotyczącego taktu pedagogicznego w takich obszarach jak: etos zawodowy nauczyciela, świadomość wychowawcza rodziców, zaangażowanie uczniów w organizacje i stowarzyszenia społeczne, a także tożsamość dzieci i młodzieży we współczesnej kulturze. Natomiast w słowach podsumowujących zwrócił on uwagę na kwestię znaczenia taktu pedagogicznego w dobie globalizacji. Zaznaczył, że „nauczyciele mogą w tym obszarze podjąć wiele wartościowych działań, ale przede wszystkim muszą sami przyjść do swoich uczniów z taktem pedagogicznym. Przestrzeń ich działań ma więc zachęcać do promowania sympatyczności zachowania i tym samym do przekonania, że jesteśmy szanowani i potrafimy także szanować innych" (s. 187).

Należy podkreślić, że autor wieloaspektowo zaprezentował podejmowane zagadnienie, celem uświadomienia różnym podmiotom edukacyjnym istotności postępowania według tej wartości, a także wskazał konsekwencje wynikające z ich nietaktownego zachowania. Dlatego nauczycielom niezbędna jest wiedza na temat taktu pedagogicznego, aby mogli budować przyjazne środowisko wychowawcze, a przede wszystkim tworzyć wartościowe relacje interpersonalne w zakresie działalności dydaktyczno-wychowawczej. Takt pedagogiczny jest niebywale ważnym elementem skutecznej pracy pedagoga każdej specjalności, wyznacznikiem jego sukcesów zawodowych.

Trzeba podkreślić, że J. Michalski podjął się analizy zagadnienia, które na gruncie polskiej pedeutologii dotychczas było bardzo rzadko przedmiotem analiz. W literaturze pedagogiczno-psychologicznej nie ma pracy, która całościowo opisywałaby tematykę taktu w pracy nauczyciela. Poprzez podjęcie tej tematyki autor powrócił do ważnego zagadnienia dotyczącego osobowości nauczyciela, które współcześnie zostało zdominowane przez kwestie związane z rolą społeczną pedagoga oraz systemem jego kształcenia i dokształcania zawodowego.

Ponadto należy docenić istotność podejmowanego przez autora zagadnienia w kontekście współczesnych przemian społecznych, kulturowych, ekonomicznych. Tematyka taktu pedagogicznego obejmuje wartości etyczne takie jak dobro, dobroć, delikatność, zdolność do wybaczania w relacjach międzyludzkich. Te wartości stanowią również główną oś w procesie budowania relacji pomiędzy nauczycielem a uczniem, a zarazem wpływają na skuteczność jego działalności. Jest to szczególnie istotne dzisiaj, kiedy w relacjach z młodym człowiekiem pojawiają się postawy egoistyczne, roszczeniowe oraz ekspansywne, zorientowane na osiagnięcie własnego sukcesu, bez uwzględniania stanowiska drugiej osoby. 
Na podkreślenie zasługuje różnorodna podstawa źródłowa, którą autor wykorzystał do zaprezentowania wybranych zagadnień. W recenzowanej pracy J. Michalski odwołał się do dorobku prekursorów myśli pedeutologicznej, a także wskazał współczesnych twórców koncepcji pedagogicznych w kontekście poruszanej problematyki. Jednak uważam, że autor powinien odwołać się również do poglądów takich uczonych jak: Antoni Smołalski, Jan Legowicz, Janusz Homplewicz, Stanisław Korczyński, Katarzyna Olbrycht, Stanisław Jamroszko, Alicja A. Kotusiewicz, Małgorzata Bednarska, Joanna M. Łukasik, aby wzbogacić prowadzony dyskurs o ustalenia badawcze niezbędne do zaprezentowania wybranej problematyki.

W sumie należy stwierdzić, że książka jest wartościową pracą w zakresie pedeutologii, gdyż zaprezentowane w niej treści stanowią zachętę do wdrażania kategorii taktu pedagogicznego do własnej działalności dydaktyczno-wychowawczej. J. Michalski ukazał takt jako szczególnie ważny aspekt w tworzeniu sztuki nauczycielskiej, w dążeniu do profesjonalizmu pedagogicznego. Dlatego recenzowana książka jest godna polecenia nie tylko osobom związanym z edukacja, czyli nauczycielom, wychowawcom, edukatorom, studentom czy zainteresowanym problematyką pedeutologiczną, ale także tym niepracującym w oświacie, aby mogli poznać i lepiej zrozumieć czynniki warunkujące wykonywanie profesji pedagogicznej.

Jednak należy mieć świadomość, że zagadnienie dotyczące taktu pedagogicznego jest nadal otwarte na nowe rozważania i wciąż aktualne, ponieważ w życiu codziennym, w zmieniającej się rzeczywistości społecznej, kulturowej, politycznej oraz ekonomicznej, pojawia się wiele nowych kwestii bezpośrednio związanych z profesją nauczycielska, które w dalszej perspektywie czasowej będą wymagały pogłębienia lub zmiany sposobu postrzegania tej problematyki.

\section{Bibliografia}

Baley, Stefan. Psychologia wychowawcza w zarysie. Warszawa: 1958.

Burzyński, Grzegorz. Takt pedagogiczny w wychowaniu wspótczesnego człowieka. Lublin: 1937.

Choma Wincenty. „Takt pedagogiczny”. Ruch Pedagogiczny 3 (1961).

Herbart, Johann Friedrich. Pedagogika ogólna wywiedziona z celu wychowania. Warszawa: 1912.

Mysłakowski, Zygmunt. Tresura czy wychowanie. Nowa Szkoła 11 (1969).

Mysłakowski Zygmunt. 1971. Pisma wybrane. Warszawa. 
Radziewicz, Julian. „Takt i nietakt w wychowaniu”. Nowa Szkoła 5 (1996). Rowid, Henryk. Podstawy i zasady wychowania. Warszawa: 1957.

Dorota Grabowska*

\section{Tomasz Piechniczek, Kultura i religijność w życiu miejskiej spoteczności lokalnej. Socjologiczne studium przypadku. Kłodnica w Rudzie Slaskiej, Katowice: Studio NOA Ireneusz Olsza, 2015, ss. 280.}

DOI: http://dx.doi.org/10.12775/PCh.2015.022

Nakładem Wydawnictwa Studio NOA Ireneusz Olsza opublikowana została w 2015 roku praca Tomasza Piechniczka pod tytułem: Kultura i religijność w życiu miejskiej społeczności lokalnej. Socjologiczne studium przypadku. Kłodnica w Rudzie Ślaskiej. Jak podaje Autor we Wstępie, postanowił on ,„poddać analizie fenomen kłodnickiej religijności, traktując parafię jako grupę społeczną, badając jej funkcje i strukturę społeczną [...] oraz dostrzegając w religii i religijności istotny element lokalnej kultury, współkonstytuujący ład społeczny" (s. 10).

Recenzowana książka składa się z ośmiu rozdziałów. Trzy pierwsze zostały poświęcone omówieniu teoretycznych zagadnień pracy. Autor wyszedł od rozważań na temat sposobów rozumienia kultury (na gruncie socjologii), by następnie przejść do określenia roli kultury w kształtowaniu tożsamości zbiorowej (rozdział 1, s. 13-36). W rozdziale drugim (s. 37-78) - opartym na analizie bogatej literatury przedmiotu - zaprezentował wybrane ujęcia socjologiczne religii i religijności, omówił społeczno-integracyjne funkcje religijności, a także poruszył problem praktyk religijnych jako manifestacji przynależności do wspólnoty lokalnej. Dopełnieniem teoretycznej części opracowania uczynił rozważania dotyczące specyfiki tożsamości lokalnej Kłodnicy, poświęcając szczególną uwagę kościelności kłodnickiej jako formie kultury lokalnej (rozdział 3, s. 79-104).

W rozdziale czwartym przedstawione zostały założenia metodologiczne podjętych badań (s. 105-122). Autor rozpoczął od określenia przedmiotu

* Dr Dorota Grabowska - absolwentka pedagogiki i historii, pracownik nieetatowy w Wydziale Nauk Pedagogicznych Uniwersytetu Mikołaja Kopernika w Toruniu. Adres: Wydział Nauk Pedagogicznych UMK, Katedra Historii Wychowania, ul. Lwowska 1, 87-100 Toruń: e-mail: dogra@umk.pl. 